УДК 821.163.41-31.09 Црњански М. https://doi.org/10.18485/godisnjak.2021.16.9

Софија Д. Филипов* Универзитет у Београду

Филолошки факултет
Оригинални научни рад

Примљен: 28. 09. 2021.

Прихваћен: 05. 11. 2021.

\title{
ГУБЉЕЊЕ ЛОГИЧКИХ ВЕЗА У РОМАНУ О ЛОНДОНУ
}

Последњи роман Милоша Црњанског обележен је сударом између једног човека и вароши. Иако приповедач разоткрива наличје либерално-капиталистичког друштва, чини се да одсуство сваке везе између Лондона и Рјепнина није последица само унификујућих тежњи овог града, већ и немогућности Лондона да главном јунаку пружи једину ствар која му је потребна: да буде Петерсбург. У том смислу, у раду се проблематизује теза да је ово, како сам роман тврди за себе, највише роман о Лондону. Питање губитка смисла, односно, логичких веза постаје кључно након напуштања домовине, док је Лондон тек симбол света у коме не више не постоји логичка уређеност, што ће имати последице и по саму форму овог романа.

Кључне речи: Милош Црњански, Роман о Лондону, логичке везе, сврха, Лондон, Русија, поетика, високи модернизам, постмодерна, метафикција.

\section{Осврт на историју тумачења Романа о Лондону}

На питање које дело сматра својим најбољим остварењем Милош Црњански, у једном интервјуу из 1957. године, одговара следећим речима:

Мој роман, који сам био написао на енглеском, под насловом The Shoemakers of London (Лондонски обућари). Писао сам га у Финчију, једном предграђу Лондона, године 1946/47, када сам био са својом женом врло близу самоубиства. Доцније сам ту ствар преписао на српски, под насловом Роман о Лондону и тако ћу га

*sofija.filipov1@gmail.com 
штампати, кад томе буде било време. Зато га сматрам најбољим остварењем, што га је сам живот писао, а ја сам само нашао фантастичну литерарну форму (Црњански 2017: 23).

Иако писац истиче фантастичну литерарну форму свог тада још увек необјављеног романа, он у исти мах говори и о некој врсти аутофикционалности, или макар писања које прати налог једног посебно тешког искуства, и тако истиче заправо обе стране онога што види као посебну вредност овога дела. Упркос томе, у критици је Роман о Лондону, чини се, и данас понешто скрајнут уколико се погледа у односу на положај који је заузела Друга књига Сеоба. То не може изменити чињеница да је Црњански управо за Роман о Лондону, када је угледао светлости књижевне позорнице 1971. године, добио Нинову награду за роман године, јер је она, по свој прилици пре свега из политичких разлога у време Друге књиге Сеоба изостала. Остаје отворено питање колико је вредност Романа о Лондону препозната у датом тренутку, а колико је награда уручена, заправо, великом имену Милоша Црњанског, као нека врста надокнаде и „прања руку” од претходних одлука. Ипак, остаје јасно да српска култура на посебан начин прихвата оно што је експлицитно српско, као што је хоризонт косовског завета у целини Сеоба и Друге књиге Сеоба, док остаје, унеколико слепа пред оним што јој је макар и привидно страно, попут судбине руског емигранта у Лондону. Стога се Другој књизи Сеоба признавала метафизичка вредност и универзалност коју Роман, наводно, у тој мери није поседовао, као што није поседовао, погрешно се чинило, ни поетичку иновативност откривања нове књижевне форме. Овај роман потцењује чак и Никола Милошевић, један од најзначајнијих проучавалаца дела Милоша Црњанског, када каже да се у њему запажа опадање пишчевог великог дара (Милошевић 1993: 40).

У наведеном суду може се, можда, ипак наслутити граница сензибилитета, а можда и разумевања књижевности и идеологије, једног тако значајног проучаваоца књижевности, која га спречава да увиди поетичку вредност романа који заокружује развој модернистичке поетике и наговештава постмодерно доба. Значај Романа о Лондону у развоју историјске поетике српске књижевности посебно је истакао Александар Јерков. У свом предговору Антологији српске прозе постмодерног доба пише о постепеном превладавању поетичких исказа у прози и позицији друге фикиионалности у првој глави Романа о Лондону: „У „Првој глави романа" којом почиње Роман о Лондону Милоша Црњанског, смењује се низ поетичких исказа, који потискује непосредно изношење приче о „расељеном” руском племићу и отвара расправу о романескном прикази- 
вању судбине, обликовању приче и ликова" (Јерков 1992а: 10). Он је значај метафикционалности у Роману о Лондону истицао и годину дана раније, у књизи Од модернизма до постмодерне, где је указао на кључну позицију овог романа на прелазу из модернистичке ка постмодерној прози (в. Јерков 1991). На тумачење постмодерности овог романа гледајући из другачијег угла, већ је инсистирала Мирјана Поповић Радовић на основу докумената и новинских чланака из живота Црњанског који су се појавили као грађа у делу (в. Поповић Радовић 1984а: 58-78; Поповић Радовић 1984б: 79-104).

На поглављу „Секс је корен свега”, у којем се појављују поменути чланци, и Мило Ломпар утемељује своје тумачење овог романа у студији Црњански и Мефистофел. Он указује на то да је у роману сусрет са ђаволом посредован симболизмом секса (Ломпар 2007: 10), а саму фигуру ђавола повезује са модерношћу, на трагу Јакова Голосовкера, који у студији Достојевски и Кант поставља Кантову филозофију, дакле, модерну филозофију просвећености, у средиште свог тумачења романа Браћа Карамазови. ${ }^{1}$ У том контексту Ломпар чин самоубиства тумачи као победу духа логике. ${ }^{2}$ Иако значајно повезује експлоатацију сексуалности са савременим добом, он радикално поларизује љубав и сексуалност, те и целину романа Милоша Црњанског подређује својој тези о прикривеној симболичкој фигури ђавола.

Слободан Владушић, са друге стране, у својој познатој студији Црьански, Мегалополис запоставља фигуру субјекта, односно Рјепнина као главног јунака Романа о Лондону, у корист мегалополиса: „град постаје јунак, јер грађане лишава воље” (Владушић 2012: 245). У његовом тумачењу наслов романа добија свој пун смисао, то, дакле, није више роман о Рјепнину него о Лондону, који је Рјепнина лищио моћи (Исто: 25). Па ипак, овакво тумачење, иако истиче (пост)модерност последњег романа Милоша Црњанског, прети да му одузме метафизичку димензију, те се поставља питање може ли субјект као такав постојати у мегалополису, односно, може ли роман бити роман о Лондону без Рјепнина. Тако су се, да их означимо у најкраћим цртама, појавиле основе контуре савременог тумачења овог дела Милоша Црњанског, у критици која има различита

${ }^{1}$ „Сада му је познато где се крио једини кривац за убиство Фјодора Павловича, ђаво са својом мистеријом. Он се скирио у Критици чистога ума, у свету четвороглавих горгона-антиномија и живео је тамо под именом Антитезе, излазећи оданде у свет под маском „науке”, поноситог асасина коме је морал далек, који тврди: „Све је дозвољено, и крај!”. Она, „наука”, као да је убила старог Карамазова. Атеистички, слободни ум - ум филозофије, Иванов ум убио је старог Карамазова. Он је симболички ђаво-убица” (Голосовкер 1983: 106).

${ }^{2}$ Из Рјепниновог крајње позитивног схватања логике не би се могло рећи да дух логике припада симболичком кругу ђавола. Више о томе у одељку Велико Н. или бесмисао историје. 
поетичке или књижевноисторијске, херменеутичке или само интерпретативне циљеве.

$$
\text { Роман - о Лондону? }
$$

Након казивања приповедача о нужности силаска са сцене, што је поетички коментар и исказ који оцењује целину човековог живота којим почиње роман, на сцену овог поетичког казивања излази Николај Рјепнин, или, барем, његов глас. Њега приповедач чује, јунак му довикује. Дакле, његова прича не почиње сама од себе, започиње је Рјепнин својим наметањем приповедачу: „Књаз, Николај Родионович Рјепнин, офуцан, усамљен, стајао је сад тамо. Нико тог човека, при изласку, није ни погледао. Нико му ни имена у Мил Хилу није знао. Разоружаних Пољака било је, тада, у Лондону много. Тај човек је, међутим, ову причу започео” (Црњански 2006: 11). Преплитањем антиномичних исказа - пуног имена са титулом уз порицање значаја том имену, и припадања мноштву потом издвајањем из тог мноштва - остварује се утисак борбе унификујуће урбане силе и субјективитета, борбе за реч, односно, за овај роман, која не престаје ни на следећим странама:

Тим куцањем у та врата отпочиње идуће поглавље ове приче. Биће то прича, не само о том човеку у Лондону, и његовој жени,[...] А највише о тој, огромној вароши, чији је загрљај био смртоносан за толико људи и жена, а која све то гледа, нема, као нека безмерна Сфинга, која слуша како пролазник за пролазником пита: „Где је ту срећа? Каквог тај улаз и излаз пролазника, у самоћи, и гомилама, - четири, осам, четрнаест милиона? - има смисла?" (Исто: 15).

На крају „Прве главе романа” приповедач истиче како ће прича која следи, иако је започиње кнез Рјепнин, највише бити о Лондону, великој и смртоносној вароши која у наведеним редовима добија особине митског чудовишта. Један од њених најзначајнијих извора моћи јесте управо повлашћен централни положај који обликује слику света и преноси је даље (Владушић 2012: 15). Слика света која се обликује у Лондону типична је слика Западног либералног друштва (в. Шкорић, Кишјухас 2014: 110), у чијој је идеолошкој основи тежња за људским слободама, индивидуализацијом и напретком, али која се готово нужно доводи у везу са капитализмом, те од идеје либералног друштва, углавном, остаје само идеја „слободне” трговине. Тако долази до изобличавања либералистичке идеологије, односно до онога што се може назвати притајеним убицом пројекта модерне. ${ }^{3}$ Дакле, нису само ужаси нацистичких логора и стаљи-

${ }^{3}$ „Међутим, победа капиталистичке технонауке над осталим кандидатима за крајњи циљ универзалне људске историје други је начин уништења пројекта модерне под привидом његовог реализовања" (Лиотар 1995: 26). 
нистичких гулага, производа радикалне злоупотребе везе између знања и моћи, изокренули просветитељске идеале, већ то, дискретније, чине и капиталистичка друштва у којима све добија своју вредност ${ }^{4}$, односно цену, и постаје предмет трговине: „Новац има, у времену у ком живимо, снагу Сунца, снагу, коју сузе више немају. Срећа људска је сад у новцу. Енглези су од трговине начинили религију. Кад се у Лондону пита ко је ко, колико вреди ко, - 'how much is he worth', - мисли се: колико има? Колико фунти? А ми, у руској емиграцији, сад, не вредимо ништа" (Црњански 2006: 32). Егзистенција руских емиграната свела се у Енглеској на новчану вредност, вредност коју су они изгубили, а пошто не могу учествовати у трговинском ланцу, након рата губе сваки значај:

Тако ми прича тај у вагону, док под земљом јуримо, а тврди, да је, док је рат трајао, било боље. „Egalité; Fraternité”, - каже. Лондон је горео. [...] Обећавају да ће их запослити. Обећавају. „So sorry, тако им је жао”, - кажу. [...] Зашто да живе? Зар зато да буду расељена лица? Перемешченаја лица? А били су Енглезима добри, док је рат трајао (Исто: 9).

Поступајући по свом војничком инстинкту, Рјепнин испрва налази сврху свом животу у Лондону и не уочава трговински дух Енглеске, који обухвата сва животна поља. ${ }^{5}$ Долазећи из другог света, јунак Црњанског и у Лондону природно узима на себе улогу заштитника земље у којој живи, a, заправо, несвесно постаје део трговинског ланца у коме свакодневно нуди свој живот у замену за саму могућност живота у Лондону. Када се рат заврши, он престаје бити оно што називају „useful” (в. Црњански 2006: 31), те бива суочен са динамиком мегалополиса ${ }^{6}$ која се оспољава у метаморфозама, облику постојања који приказује сву нестабилност и децентрираност света који га окружује. ${ }^{7}$ У Лондону је све подложно

${ }^{4}$ „Нисам ништа рекао о капитализму. Радо бих тек напоменуо: начело по којем су прихватљиви сваки предмет и свака акција ако могу ући у економску размену није тоталитаран у политичком смислу, али он то јесте у језичким изразима, јер призива потпуну хегемонију жанра економског дикурса" (Исто: 59).

${ }^{5}$ „Невоља капитализма, у овом као и у другим случајевима, јесте то што он разара људске потенцијале које је створио. Он код свакога подстиче, чак намеће, саморазвој, али људи могу да се развијају само на ограничен и деформисан начин. Оне особине, импулси и таленти који су корисни на тржишту форсирају се (често преурањено) и неразумно цеде до краја. Све друго што у човеку постоји, све што нема тржишну вредност, немилосрдно се потискује, или усахњује због неупотребе, или никада не добија шансу за заживи" (Берман 2018: 93).

6 „Мегалополис тако постаје простор у коме човек више не може претендовати на статус темељне тачке из које се, и за коју се, организује свет око њега. Темељ, укорењеност, статичност, све су то вредности које динамика Мегалополиса доводи у питање" (Владушић 2012: 293-294).

7 „Динамичности урбане мреже, кретање урбане енергије кроз тачке Мегалополиса, није отуда само негација идеје апсолутног идентитета, него и негација просветитељске матрице 
променама, чак и пол ${ }^{8}$, што Рјепнину пружа волшебну слику света у ком не постоји никаква укорењеност. ${ }^{9}$ Ако постоје метаморфозе у нечему што би требало да је иманентно људском бићу, није нимало чудно да се оне могу манифестовати и на њему, који није својствен земљи у којој у том тренутку живи. Оне су не само израз капиталистичке динамике већ и принцип који влада светом и имплицира начин његове уређености, односно неуређености. У таквом неуређеном свету, јунак осећа сву дубину сазнања да је расељено лице, категорија која укида сваки смисао, а од њега се очекује да одбаци оно што је суштински био и пристане на нов, користан, идентитет. ${ }^{10}$ Непристајањем на овакве захтеве капиталистичког света, више него самом чињеницом да је Други у лондонском свету, односно премештено лице, Рјепнин не само што бива смештен на друштвену маргину и у аутсајдерску позицију (в. Мајер 1981). већ долази и до постепене дезинтеграчије његовог идентитета. Име Николаја Рјепнина празни се значењем, те презиме које је означавало кнежевску породицу и тиме било симбол моћи, сада постаје неизговорљиво и доживљава чудне метаморфозе, док се име Николај укида и постаје Нико. ${ }^{11}$ Онога тренутка када јунак поунутри виђење себе као „никога”, дакле када то више није само перцепција урбане средине, долази до коначне детронизације кнежеве личности:

Нешто је, и даље, као неки досадни бумбар, у ушима зујало и мрмљало, да није у Русији, да није у Петерсбургу, да није млад, да није поред Сазанова, нити је његов отац, са Бенкендорфом, на трибини, да је, просто, гоља, нико и ништа у Лондону, који има једно једино, цело, одело, какво је Едвард VII носио. [...] Зашто је био кукавица, зашто није играо, све, на вранца, којег је био изабрао? Зар није више

која промене види као напредовање разума. Урбане метаморфозе нису никакво напредовање, већ пре свега трошење система који доводи до нечитљивости постмодерног града" (Исто: 318 ).

${ }^{8}$ „Постоје, дакле, чудне метаморфозе, не само у животу људском, у природи, геологији, него и у сексу?” (Црњански 2006: 149).

${ }^{9}$ Та могућност потпуне нестабилности у капитализму, код Црњанског иде корак даље од славних најава Маркса и Енгелса из Манифеста, и претходи тумачењима која су доцније давали Берман и Жижек. Утолико се види далекосежно, метафизичка и дијалектичка, у исти мах, дубина коју књижевно дело када је у рангу имагинације Милоша Црњанског може да постигне.

10 „Задатак је Енглеза, сад, да тај свет науче благодетима мира. Да се ти војници и бескућници претворе у корисне чланове друштва. Зидаре, обућаре, штаваре кожа, столаре, браваре, рударе, носаче, месаре, болничаре" (Исто: 13).

${ }_{11}$ „Међутим, његово име у Лондону ником ништа не значи. Не значи, уопште. Као контраст јављају се јунаци - носиоци презимена „са значењем”: господин Божић, господин Зелени. А презиме овог човека нити ишта значи на енглеском, нити се може изговорити. И тако, за разлику од јунака првог романа, чије име и презиме можемо покушавати да дедукујемо, јунак Романа о Лондону губи овде своје презиме. Рјепнин постаје Риепејн, Џејпин, [...] Николај постаје Нико" (Татаренко 2012: 62). 
књаз, руски? Којешта! Где? У Лондону? Којешта! У Лондону је нико и ништа. Слава Богу! Нико и ништа! (Црњански 2006: 445).

Одузимање воље ${ }^{12}$ јунаку резултира његовим прихватањем униженог идентитета, те се појачава већ изражени контраст између сјајне прошлости ${ }^{13}$ и ништавне садашњости. Управо тај контраст онемогућава кнежеву садашъост. Рјепнинова измештеност из домовине ствара дисконтинуитет у његовом идентитету који се заснива на прошлости, те се на тај начин не може наставити у Лондону, али се, исто тако, од њега не може ни одустати. Зато кнез у Лондону не може бити useful, и зато постаје Нико и корача ка потпуном нестанку:

Корен његове несреће, његове неспособности да се снађе, у туђини, у Лондону, учини му се, изненада, да је само, то, што је он, просто, потомак војника, Рјепнина, маршала, фелдмаршала, официра. Он је официр. Не инжињер рударства, како је ујак желео да он буде. Руски официр. То је корен све његове несреће у туђини, па и у Лондону. Био је војник. То је корен свега: „That's the root of everything”. (Исто: 318).

Иако се не може оспорити мегалополису моћ која човека лишава снаге (в. Владушић 2012: 25), у Роману о Лондону није реч само о немогућности живота у мегалополису већ о немогућности бивствовањ $a$ аутентичног субјекта у њему, а нарочито оног који истим интензитетом којим Лондон тежи њега да измени, жели од Лондона да буде нешто сасвим друго: град његове младости, Петерсбург. Тако нас колебање идентитета као питање метафизике, дијалектике и револуције, са једне стране, а однос према токовима капитализма који мењају смисао и сврху модерности, или у свом завршном, позном облику постмодерности, односно обликују претећу фигуру мегалополиса, доводе до једног посебног и по много чему изузетног контекста који Роман о Лондону ствара и у којем, веома широком, епохалном захвату, српска књижевност добија посебан квалитет. Корак од, коликогод значајне фигурације националног завета и романа једног национа у развоју од Сеоба до Друге књиге Сеоба, и онај корак који истовремено следи и претходи у делу Код Хиперборејаца, до овог поетичког достигнућа у Роману о Лондону, има изузетан значај за савремену српску књижевност. И умногоме одређује положај Романа о Лондону у њој, а тај је по свему овоме судећи још виши но што се то

${ }^{12}$ „Најгоре је што им је ова страшна варош одузела и оно, последње, у животу човека, што је светло у човеку. Вољу” (Црњански 2006: 267).

${ }^{13}$ Сјајну Рјепнинову прошлост чини суштинска припадност Руском царству: припадање њеној и аристократији и армији. 
показује у неким читањима која застају на неоспоривим достигнућима Друге књиге Сеоба.

Он је Рус. И остаће то до смрти. То је логично.

Напуштајући своју земљу, Рјепнин губи битни хоризонт свог бивствовања, сврху коју не може поново пронаћи нигде, а посебно не у Лондону у којем живот мора да тече као да је то што је ту све што је од живота преостало. Стога се Рјепнинова драма не тумачи само као роман о бесмислу живота једног руског емигранта $y$ Лондону него као универзална драма изгубљене сврхе:

Сломило га је, то, да им се живот, кад су из Русије изашли, претворио сад већ годинама у непрекидну самоћу, беду, беспосленост, као неки страшан сан, из којег не може да се пробуди. Нигде није могао да се скраси, нигде ни да живи и зарађује, као други људи. Живот им је постао, не само тежак, него и чудноват, бесмислен, невероватан” (Црњански 2006: 38).

Најпре, живот не постаје тежак тек у Лондону, већ се радикално мења и пре изласка из Русије, а проблем не лежи само у економским приликама и Рјепниновој немогућности да пронађе посао којим би издржавао своју породицу, већ у наглашеном одсуству смисла, понижењу и самоћи која постаје егзистенцијални проблем: „Није то била последица само тешког живота руског емигранта, него, много више, огорчења да, он, потомак Аниките Рјепнина, живи тако, понижен, у туђини" (Исто: 502). Лондон је тек симбол једног новог света у коме јунак попут Рјепнина више не може постојати. Зашто је онда Лондон издвојен у односу на Париз или Праг? Пред живот у Лондону постојала су очекивања, афективна очекивања, која су потом изневерена. ${ }^{14}$ Лондон је град коначно срушених илузија, град који је обећавао причу о сврховитости, причу о напретку, која би надокнадила јунаков губитак домовине. Када увиди капиталистичку обману, јунак ће се наћи у позицији знања које разоткрива привид модернитета и где никакав наратив који обећава смисао, а који је јунаку нужан, није могућ. ${ }^{15}$ Николај Рјепнин је суштински модернистички јунак јер му је неопходна

${ }^{14}$ Ентузијазам који је постојао у Рјепнину, за време рата, када је Лондон горео а он није желео ни у једном тренутку да га напусти, део је наслеђа његовог оца, највећег англофила у Думи: „Отац га је учио, уверавао, а он му је поверовао, да ће, овде, наћи, неког његовог „идеалног човека”: Енглеза, - либерала. Он је то изговарао повишеним гласом: „либерала” (Црњански 2006: 298).

15 „Онога тренутка када себе затекне у привиду модернитета које га окружује, савремени човек је већ закорачио у постмодерно доба. Стање знања које стварност утврђује као привид је основа постмодерног покрета духа" (Јерков 1992а: 50). 
велика, телеолошка прича ${ }^{16}$, али се налази у свету у коме таквих прича више нема, у свету којим владају бесмисао и чудне метаморфозе. Управо се на овом месту види допринос Црњанског ономе што Рансијер назива поделом чулног ${ }^{17}$, јер у свом роману, започетом по сопственом сведочанству још 1946. године, наслућује обрисе једног новог доба и приказује однос модернистичког субјекта према постмодерном свету.

Дакле, губитак смислености ${ }^{18}$ поставља се као кључан проблем Рјепниновог живота након напуштања домовине. Када тај смисао не буде био пронађен ни у либералистичком Лондону, идеалу кнежевог оца, Рјепнину остаје меланхолично, можда чак и циничко, сазнање да нема повратка, али ни напретка, те ни икаквог смисленог бивствовања у будућности, што доводи и брачну срећу, после толико година, у питање. ${ }^{19}$ У мери у којој Рјепнину и христијански и супружнички вид спасења у љубави остаје стран, оцртава се скептичко биће онога који је своју веру поверио негде другде, у најмању руку тамо где је постојала друга врста општости као мера човекове сврхе и самог бивствовања. Суитина његовог бића налази се, или је ту чвршће дезигнирана, у војничком позиву, који у јунаковој визури садржи одређен идеал понашања. Он подразумева изражен принцип части, осећај заједништва са саборцима, као и апсолутну верност земљи. ${ }^{20}$ То знатно усложњава већ амбивалентне релације између

16 „Под метапричом или великом причом ја разумем саму нарацију чија је функција позакоњење” (Лиотар 1995: 27).

17 „У питању је један начин утицаја на поделу чулног која дефинише свет у коме живимо: начин на који је тај свет за нас видљив, и начин на који тај свет допушта да буде исказан и способности и неспособности који се при том приликом испољавају” (Рансијер 2008: 11).

${ }^{18}$ Виктор Франкл у својој књизи Зашто се нисте убили? проблем губитка смисла одpeђује као, пре свега, филозофско питање (в. Франкл 2019: 106).

${ }^{19}$ „Нађа, жељна бар љубави, у том бедном животу, примећује да јој је муж охладнео према њој. Пита се, у себи, да ли је можда жељан неке друге жене, или почиње да стари? А зна да, опет, мисли на самоубиство" (Црњански 2006: 30). Нађа у љубави према мужу проналази утеху и сврху, те је и њен живот у Лондону, као и однос велике вароши према њој, блажи у односу на Рјепнина. Кључно је то да се Нађино биће остварује у љубави, док Рјепнин, иако воли своју жену подједнако и све би учинио за њу, не проналази такву врсту спасоносне потке бивствовања. Како је Рјепнинова сврха у прошлости, он све више бива увучен у њу и постаје све даљи од живота, док Нађу љубав одржава у симболичком кругу животворног принципа: „Разлика која се испољава преко њихове сексуалности своје исходиште има у разлици на којој приповедач инсистира од самог почетка - на разлици између живота и смрти” (Пантић Мараш 2017: 315).

${ }^{20}$ Душан Пувачић тумачи Рјепнинову свест о достојанству као „део класног комплекса који је толико снажан да он чак не жели да се упушта у љубавни однос са женама из средње класе” (Пувачић 1973: 722), што се може проблематизовати ако се „средња класа” не тумачи у уском смислу друштвеног уређења, него се схвати као апстрактно-морална категорија. Тако би се Рјепнинова свест о достојанству разумела као део војничког, можда чак витешког, кодекса понашања, који је присутан код већине главних јунака Црњанскових романа. То се најпре види 
сурове вароши и јунака, те се однос Лондона према Рјепнину делом може сматрати симболичком пројекцијом Рјепниновог односа према Лондону. Највећу препреку остваривању везе између јунака и града представља суштинска припадност и обележеност кнеза земљом и традицијом у којој је рођен, што га онеспособљава да оствари своју егзистенцију било где осим у месту одакле је измештен. Остајући у новом свету веран ономе што је прошло, Рјепнин не остварује везе са новим окружењем и постепено остаје све више сам, иако крај себе и за себе има жену која га воли и коју он воли. Живот у сећању, живот у прошлости ${ }^{21}$, онемогућава кнеза да постоји, у правом смислу те речи, у садашњости, јер оно што је некад било превладава све временске аспекте кнежевог живота. ${ }^{22}$

Живети у Русији било је смислено: „Он је Рус. И остаће то, до смрти. То је логично. Он цени логику више свега, и, песму руску воли више свега. Сећа га Русије. Сећа га младости. А рат је прошао. Сад је мир" (Црњански 2006: 308). Рјепнин цени логику више од свега јер то је оно што његовом животу недостаје од изласка из Русије. Живети у земљи у којој си рођен и бити у њеној армији био је логичан живот за руског кнеза, живот који је обесмишљен Бољшевичком револуцијом и емиграцијом. Кнез је био део логоцентричног система, он је рационални мушкарац који највише цени логику и налази се у позицији наслеђене вишевековне моћи. Наједном је од свега тога отргнут и на крају доспева у Лондон, где се његов положај радикално мења и он постаје Друго, што у потпуности урушава његову концепцију света као онога што је својим рођењем затекао и што се одгојем устројило, а чврстом вољом посвећености сталежу и позиву усвојило - логички уређеног. Никакве везе, односно, никакве логичке везе нема између његовог некадашњег, и овог лондонског положаја. Оне

\footnotetext{
у сфери сексуалног која је потпуно подређена војничком: „Да је могао да помогне несрећном Ба̀рлову, који се убио, срце би му, можда, још једном радосно, заиграло, али за ту лепу девојку, не би. Ни у џаку" (Црњански 2006: 115). Мило Ломпар пак сферу сексуалног приписује ђаволском комплексу у роману, поларизујући је можда и превише радикално у односу на љубав. Тако је приближава принципу смрти (в. Ломпар 2007: 25), што се супротставља Фројдовом учењу о нагонима: „Сексуалност је велики изузетак у кретању живота према смрти, зато што живот иде у смрт. Танатос открива смисао Ероса као онога што се опире смрти” (Рикер, 2010: 280).

${ }^{21}$ Иако обоје у мислима теже прошлости, Нађин објект жеље, Рјепнин, налази се крај ње, док је Рјепнинов објект недостижан: „Тада, пре него што заспу, у ћутању, обоје живе у прошлости. Она се сећа првих година њиховог брака, а он Русије” (Црњански 2006: 30).

22 „Фиксиран у прошлост, назадујући у рај или пакао непролазног искуства, меланхолик је чудно осјећање: све је довршено, изгледа да ће рећи, али ја сам вјеран тој довршености, ја сам тим прикован, не постоји могућа револуција, без будућности. [...] Хипертрофирана хиперболична прошлост заузима све димензије психичког трајања" (Кристева 1994: 79).
} 
се могу остварити само као чудновате и обеспокојавајуће, доказ лоше уређености света:

Оно што је некад било, и оно што се догађа са њим, сад, у садашњости, у некаквој су, дакле, чудноватој вези? А он сад, ето, желео би да буде оџачар у тој вароши. Како је чудна та блискост, онога што се давно дешавало, и што је прошло, и оног, што се сад са њим догађа. Можда и са оним, што ће се догодити, у будућности? Како су страшне те нагле промене у животу људи. [...]

А нема више ни тог Петербурга, у ком су, у детињству, учили енглески, нема више, ни те учитељице. Ујехал! Све се мења, али он, ето, не може ни толико да се промени, да га приме, у Редингу, оџачари (Исто: 62).

Трагање за логиком заправо је трагање за чврстом потком и уверењем да свет ипак јесте, онако како се то може сагледати и растумачити, смислено уређен. Рад на тапетама са геометријским фигурама наизглед пружа пример такве уређености и Рјепнин напокон добија осећај да ради нешто смислено: „Рад молера, међутим, био му је сваки дан, све милији. Најзад је радио нешто што има смисла. [...] Блокови тапета, које је требало тачно прилепити, били су пуни линија, које је требало повући, тако, да се додирују тачно, од тачке до тачке. Онако како су повучени, логично, као да су логаритми" (Исто: 489). Тапете, ипак, показују Рјепнину да је чак и оно што делује логично продукт произвољности, те да ништа није сигурно и извесно ${ }^{23}$, а бесмисао се преноси на универзални план, што ће и овом детаљу у обликовању роман и карактеризацији јунака, процепа његових идеја и виђења, дати значај.

Трагичност последњег романа Милоша Црњанског лежи у изгубљеном смислу ${ }^{24}$, који се не може повратити ${ }^{25}$, а који чак ни љубав не може надокнадити. Ово је роман испражњене трансценденције и својеврстан пут ка постмодерној кризи, одговор на старозаветну причу о изабраном народу када више не постоји сврховитост која би оправдала измештање: „Пренеразило га је, то, да таквих промена ИМА у животу. Питао се, је ли тај несретник, зато, отишао из Русије, да у Ексетеру доживи, то? Је ли зато морало доћи до рата, до револуције, до руске емиграције, по целом земаљском глобу, да би тај Рус у Енглеској постао, то, што је постао?"

${ }^{23}$ „Ти тапети су били квадрати, трокути, кругови, а на зиду, а на крају крајева, ипак, само случајне збрке. [...] Зидови, већ скоро допола покривени геометријским сликама, говорили су му, својим леденим говором логике, као да је у некој гробници, да нема, и не може бити, за човека, утехе, у Богу, Оцу, Творцу, или у пиву, или у бесмислу света, и свему, што ради, него само неочекиваних и бесмислених људских мисли и људског рада. Случаја који су последица људског живота. Игра боја, тачки, линија, па ни то није сигурно" (Црњански 2006: 490).

${ }^{24}$ Рјепнин не проналази дубљи смисао у својој измештености, те ни сврху таквом животу. За разлику од Виктора Франкла, он не прави разлику између логоса и логике: „У логотерапији, у том контексту, говоримо о надсмислу. Од човека се не тражи, како уче неки егзистенцијални филозофи, да подноси бесмисленост живота, већ радије да призна своју неспособност да схвати безусловну смисаоност живота разумским појмовима. Логос је дубљи од логике" (Франкл 2019: 108).

${ }^{25}$ „Васкрса, капетане, за оно, што је прошло, нема” (Црњански 2006: 312). 
(Исто: 186). У свету у коме владају чудне метаморфозе и у коме не постоје логичке везе, судбина добија лик радикалног индетерминизма, а живот постаје комедијант (в. Исто: 302). Тако се једном речју којој је Црњански придао посебна и промењена значења, уједињује књижевноисторијски хоризонт од раскола трагедије и комедије, до света кризе модерности и њеног растакања, у којем је комедијантски лик судбине, догађаја и истине нешто сасвим друго: име за свет у којем су истина и догађај, онако како су одређени и у историји мишљења двадесетог века о овим појмовима, укинути сами у себи, а нужни, и даље, у нашем ишчекивању. Ту роман Милоша Црњанског превазилази време у којем је писан, па чак и тренутак у којем је објављен, да би собом одредио целу ову епоху друге половине двадесетог века.

\section{Велико Н. или бесмисао историје}

У радикалној неуређености светом владају чудне метаморфозе које потпуно обесмишљавају историјске процесе, те кнез Рјепнин, који је битно укорењен у свом сталежу и позиву, након револуције може постати исељено лище и лондонски обућар. То чини нарочито значајним јунаков дијалог са историјском фигуром која се нашла у обрнутој ситуацији и постала чувени император Бонапарта. Комедијантска игра судбине револуцијом лишава Рјепнина смисла ${ }^{26}$ и уклања га са позиције моћи, док Наполеону управо она отвара врата ка историјској сцени ${ }^{27}$ : „Његово огорчење имало је за узрок осећај: да је судбина игра, и, да људи, па и жене, сваки час, претварају, њега, у неког другога, у неког, који није био, нити је желео да буде. Та немоћ, да се негде скраси, и, нађе мира, и спасе самоће која га je, и поред нађе, годинама, пратила, једва је подносио, при крају. Зато је

${ }^{26}$ Према Кристевој губитак смисла доводи сам живот у опасност: „,ако се губи смисао живота, безболно се губи и живот: пошто је смисао уништен, живот је у опасности" (Кристева 1994: 13).

${ }^{27}$ „Чудно име, уосталом, чудна фамилија: Buоna-parte. Револуционари су, кажете? Корзика се превија у порођајним мукама Француске револуције? Ајачо, где се Наполеоне родио, гори, попрскано крвљу? Револуционари гину, за своју земљу, у борби против окупатора. Да, да, а хоће ли Француска прознати поштованој фамилији Наполеоновој да су Buоna-parte некакви племићи?

Xoћe?

Е онда немамо ништа против окупатора, молићу лепо.

Онда ће наш мали Наполеоне, у школу, за француске кадете. Постаће, француски, официр, школоваће се муфте. Окупатор отвара пред њим врата Париза (Црњански 2006: 501).

Наполеон је, дакле, продукт Француске револуције, чије се идеје баштине у либералистичким идеологијама. Његов прагматизам доводи га у везу и са Западним капиталистичким друштвом у ком се Рјепнин обрео. 
писао Ординском и то писмо, о великом Н.” (Исто: 502). Исти неподношљиви бесмисао који га је водио кроз живот Рјепнин види и у судбини великог императора, исти случај претворио је кнеза у ништа, а Наполеона у једног од најчувенијих војсковођа, готово у симбол војевањ $а$. Но, управо случај све релативизује, те не постоји права вредност ствари, а тиме ни Наполеонова изузетност. ${ }^{28}$ Случају није важно ни то што чувени војсковођа нема војничку част и достојанство, као ни то да изневерава све оне идеале који су у сржи Рјепниновог бића; није веран Француској и саборцима већ искључиво себи, није спреман да изађе на чело војске и погине часно у борби, и његова сексуалност није ограничена осећајем части и подређена вишој сврси, што га додатно умањује у Рјепниновим мислима: „Њени плотуни, међутим, од великог Н. начинише: мало Н. - које је побегло код Ватерлоа, и, после се, предало. Није погинуло. Отишло је на острво, у океану, да коитира са госпођом Бертран” (Исто: 513).

Насупрот великом војсковођи, руски кнез истиче маршала Неја, „чија је команда, док га стрељају једина утеха, кад је реч о војнику”. (Исто: 509). Рјепнин нарочито истиче да, иако је мењао стране, Неј никада није ишао против Француске, па чак ни онда када је наређено његово стрељање - команду је сам дао. Тако Наполеонов маршал остаје суштински део своје армије и земље којој је целог живота припадао. Нејев одлазак са позорнице уз мали чин слободе, и велико достојанство које је имао при томе, постају кнежев узор часне смрти и оданости земљи у којој је рођен. Рјепнин у Нејевим поступцима види начин изласка из егзистенцијалне усамљености, која настаје јер он није део оне армије која је сада руска, која се није осрамотила у рату.

Међутим, Рјепнин ипак остаје веран земљи ${ }^{29}$, Русији као апсолуту, не уређењу или идеологији, и не жели да иде против ње ни по цену могућег повратка „белих":

${ }^{28}$ „Каже да је увек, увек, неки случај, непредвиђени случај, неки стицај околности, гурао га, у ратове, и спасавао, у животу. То је оно што, тог, тобоже великог, човека, његов живот, победе, па и његову трагедију, претвара баш у бесмисао" (Исто: 511).

${ }^{29}$ Чини се претерана тврдња Николе Ковача да Рјепнин остаје веран једино духу наро$\partial a$ : „На беспућима историје и у недосљедностима историјског ума Рјепнин је остао вјеран једино „духу народа”, тој митизованој представи о нацији која се, упркос свим превратима, диже изнад владајуће идеологије" (Ковач 1984: 49). Наиме, Рјепнин је и кнез и војник, та два ентитета остају чврсто спојена у његовој личности иако прихвата идеју нове Русије. Могло би се рећи да потомак Аниките Рјепнина остаје веран идеји славне Русије, ма каква она била, више него самом духу народа. 
А што се тиче Москве, како кажу, матушке, ни прстом маћи неће, против ње. Рат је завршен. Сад је мир. Кад би могао, сутра би се у Москву вратио, или у Санкт Петерсбург, ма какав био. Он је један, а у Санкт Петерсбургу су многи. Он је један, а у Москви су милиони. Живети у својој земљи је логично, ма какав то живот био. У туђини, није. „После свега што се десило, ја не бих, више, ни прстом, против Стаљина, макао” (Црњански 2006: 311).

Тако се остварује можда најчуднија метаморфоза у кнежевом животу $^{30}$, која је, заправо, једно необично успостављање веза између Рјепнина и нове Русије: „Нека чудна веза, међутим, све више постоји између њега, емигранта, белог Руса, и те нове црвене, руске армије. Нека чудна радост, неки понос, и у њему емигранту, кад помисли на ту армију, на Русију, у којој се родио, коју воли, иако у њу не може да се врати" (Исто: 481). Оно почиње када Рјепнин у биоскопу увиди да је марш нове руске војске идентичан старом руском кораку:

Све је било као и у старој руској војсци. Бар му се тако чинило. Било му је сасвим свеједно каква је имена команданата чуо. Оно што га је занело била је, форма, параде, те двојице на коњу. Била је иста као и бивша, стара, у старој војсци. Сабља је севнула, исто онако, као у доба кад је и он јахао, у пратњи Брусилова, у петом, или шестом реду, али присутан, насмешен и весео (Исто: 394).

Континуитет се најпре открива у ономе што му је најближе - у сфери војничког, те постепено почиње процес у којем нараста оно то је неочекивано, симпатија за Црвену армију која је поразила његову војску, али је разнела глас о руској слави даље но икада раније, док други неочекивани континуитет Рјепнин проналази у књизи са сликама Петерсбурга, односно Лењинграда. У књизи открива да је град његове младости, са свим славним атрибутима, остао нетакнут. ${ }^{31}$ Уочавањем постојаних веза између старе и Совјетске Русије, Рјепнин превладава раскол створен револуцијом и прихвата нову земљу иако он, бели Рус, у њој не може постојати. Резигнирани спокој који настаје након гледања слика Петерсбурга у књизи коју добија од графа Андрије (в. Црњански 2006: 493), последица је новоуспостављених веза, које, дакле, само додатно указује Рјепнину на немогућност остваривања његовог идентитета. Стога нестаје сваке илузије да за руског књаза постоји живот ван прошлости, јер се успоставља

${ }^{30}$ „Чуо је, међутим, како му се, у сећању, његов покојни друг, Ба̀рлов, смеје, у глави: 'Как чудниј метаморфоз, књаз! Как чудниј метаморфоз! Ви стаљинист, књаз? Ви стаљьиист!'”, (Црњански 2006: 364).

${ }^{31}$ Славни споменици Санкт Петерсбурга уједно су и неизоставан део Рјепнина, јер према речима Рикера: „Преко тих дела, посредством тих споменика образује се „достојанство” човека, који је још инструмент и траг процеса удвостручене свести, препознавања сопства у другом сопству" (Рикер 2010: 500). 
та чудна веза између њега и државе коју постепено признаје као и даље своју, али којој он као такав не може припадати. Прихватајући укидање свог бивствовања, свестан немогућности фактичког повратка ${ }^{32}$, Рјепнину преостаје само један пут: „У глави је, опет, изненада, чуо, тихи смех, и шапат, покојнога Ба̀рлова. „Нека иду бестрага, књаз, сви ти, са њиховим тражењем напретка човечанства, и боље Русије! Ми се, после наше смрти, враћамо. Шагом мари, књаз! Тако, тако, сви се, тамо, враћамо!” (Исто: 514).

Ба̀рловљев глас упућује на бесмисленост историје, јер јој се укида узлазност, а према речима Николе Милошевића: „Смислена линија историје узлазног је, а не кружног типа" (Милошевић 1998: 139). Историјска смисленост дисквалификована је у Другој књизи Сеоба довођењем у питање самог принципа сеоба. Када Павле Исакович каже царици/глумици да би само желео да још једном види Цер, брдо под којим се родио (в. Црњански 1990: 771), испоставља се да су све сеобе, према речима професора Јеркова, „водиле негде далеко само да би се човек, напослетку, вратио своме пореклу" (Јерков 1992б: 80). У Роману о Лондону такво сазнање је присутно од самог почетка, да би на крају финалним чином Николаја Рјепнина било потврђено.

Кнежев одлазак са Лондонске сиене у знаку је непристајања на нововековни бесмисао и свет без овако постављених и успостављених логичких веза. Дакле, његовим самоубиством није потврђен дух логике који би припадао ђаволовом делокругу (в. Ломпар 2007: 147), већ управо супротно, Рјепнин, уклањајући се из света у коме за њега више нема места и у коме се не може остварити суштина његовог војничког бића ${ }^{33}$, даје логичан (дакле не логички, већ логичан у овом посебном смислу) одговор на живот и свет својим ишчезнућем, и тек тако успоставља нешто што је битно и оставља за собом траг трансценденције. Његов повратак се остварује не као пародијски чин (в. Ломпар 2007: 120) већ, парадоксално, као потврђивање бића.

Рјепниновим самоубиством као чином непристајања на бесмисао, остварује се могућност остављања трансценденталног трага, трага који му омогућава да постане јунак који немо започиње причу, али не и приповедач, па је прича ту где је нестајање, и где се она не може причати онако

\footnotetext{
32 „Што се њега тиче, он је бели Рус, али не крије да воли Русију - и данашњу Русију. Кад би могао, сутра би се, у Русију, вратио. То је немогуће” (Црњански 2006: 515).

${ }^{33}$ Бити војник и бити песник може се суштински бити само у родној земљи. Ова веза може се уочити на основу верзија романа, где је у почетку главни јунак био сам писац: „Руски официр и српски песник имају нешто заједничко - остварујући суштину свог идентитета, оно што су они заиста - војник и писац, могу да испоље само тамо где су се родили, знајући у исто време да је повратак у отаџбину могућност која им је укинута" (Раичевић 2021: 565).
} 
како се напросто приповеда, испричана у одсуству самим одсуством: то је већ ултимативна поетичка самосвест романа која више не тражи приповедање, у којој се, као у одсуству приповедања, има оно све што је имало бити исприповедано. Тако прича о Рјепнину постаје поетички освешћена и заснована могућна прича о немогућем изгубљеном смислу, док Лондон постаје лик (пост)модерног света у коме је тај смисао, односно, у коме су логичне везе, изгубљене. Како би се исказао такав свет била је нужна не више поетичка самосвест већ поетичко знање и нови, другачији облици постмодерних стратегија текста.

\section{ЛИТЕРАТУРА}

Берман 2018: M. Berman, Sve što je čvrsto i postojano pretvara se u $\operatorname{dim} . . .$, у: Д. Маринковић (прир.), Modernizam/postmodernizam. Teorija, Novi Sad: Mediterran Publishing, 84-127.

Владушић 2012: S. Vladušić, Crnjanski, Megalopolis, Beograd: Službeni glasnik.

Голосовкер 1983: J. Golosovker, Dostojevski i Kant, Beograd: Grafos.

Јерков 1991: A. Jerkov, Od modernizma do postmoderne, Priština-Gornji Milanovac: Jedinstvo - Dečje novine.

Јерков 1992а: А. Јерков, Постмодерно доба српске прозе, предговор у: А. Јерков (прир.) Антологија српске прозе постмодерног доба, Београд: СК3, 7-61.

Јерков 1992б: A. Jerkov, Rađanje »romance« o nacionu iz duha tragičkog sna (o imanentnoj poetici romana Miloša Crnjanskog), y: Treći program: izbor, бp. 92/95, 59-87.

Ковач 1984: N. Kovač, Sudbina „raseljenih lica”, Roman o Londonu Miloša Crnjanskog, y: Delo: mesečni časopis za teoriju, kritiku i poeziju $\mathrm{XXX} / 3,40-51$.

Кристева 1994: Ј. Кристева, Црно сунще: депресија и меланхолија, Нови Сад: Светови.

Ломпар 2007: М. Ломпар, Црњански и Мефистофел, Београд: Нолит. Лиотар 1995: J. F. Lyotard, Šta je postmoderna, Beograd: KIZ „Art press”.

Majep 1981: H. Mayer, Autsajderi, Zagreb: Grafički zavod Hrvatske.

Милошевић 1993: Н. Милошевић, Милош Црњански као романописац, у: Н. Милошевић, Кюижевност и метафизика, Београд: Филип Вишњић, 22-41.

Милошевић 1998: N. Milošević, Ima li istorija smisla?, Priština: „Grigorije Božović”. 
Пантић Мараш 2017: Ј. Пантић Мараш, Еротско у романима Црњанског, Београд: Службени гласник.

Поповић Радовић 1984a: M. Popović Radović, Avetinjski pisac romana o Londonu, y: Delo: mesečni časopis za teoriju, kritiku i poeziju, XXX/3, 58-78.

Поповић Радовић 1984б: M. Popović Radović „Londonski period” Miloša Crnjanskog, y: Delo: mesečni časopis za teoriju, kritiku i poeziju, $\mathrm{XXX/3,79-104.}$

Пувачић 1973: Д. Пувачић, Изгнаник или проблем самоће у Роману о Лондону, у: М. Бандић (прир.), Савремена проза, Београд: Нолит, 718-730.

Раичевић 2021: G. Raičević, Agon i melanholija: život i delo Miloša Crnjanskog, Novi Sad: Akademska knjiga.

Рансијер 2008: Ž. Ransijer, Politika književnosti, Novi Sad: Adresa.

Рикер 2010: P. Riker, O tumačenju. Ogled o Frojdu, Beograd: Službeni glasnik.

Татаренко, 2012: А. Татаренко, Од Суматре до Лондона: Егзили и уточишта јунака Милоша Црњанског, у: Д. Бошковић (прир.), Егзил(анти), Крагујевац: ФИЛУМ, 53-65.

Франкл 2019: V. Frankl, Zašto se niste ubili, Beograd: Kontrast izdavaštvo.

Црњански 1990: М. Црњански, Сеобе (романи), Београд: Задужбина Милоша Црњанског.

Црњански 2006: М. Црњански, Роман о Лондону, Београд: Задужбина Милоша Црњанског, 2006.

Црњански 2017: M. Crnjanski, Duge godine stranstvovanja, y: M. Crnjanski, Ispunio sam svoju sudbinu, Beograd: Štampar Makarije, 23-29.

Шкорић, Кишјухас 2014: М. Škorić, A. Kišjuhas, Vodič kroz ideologije I, Novi Sad: AKO.

Sofija D. Filipov

THE LOSS OF LOGICAL CONNECTIONS IN ROMAN O LONDONU

Summary

Miloš Crnjanski's last novel is marked by a collision between a man and a town. Although the narrator reveals the true face of liberal-capitalist society, it seems that the absence of any connection between London and Rjepnin is not only a consequence of the unifying aspirations of this city, but also the inability of London to be Petersburg, the city of the protagonist's youth. In that sense, the paper discusses the thesis that this is, as the novel itself claims, mostly a novel about London. The issue of loss of meaning, or logical 
connections, becomes key, while London is only a symbol of a world in which there is no longer a logical order, which will have consequences for the very form of this novel.

Key words: Miloš Crnjanski, Roman o Londonu, logical connections, purpose, London, Russia, poetics, high modernism, postmodernism, metafiction. 